\title{
Dispersion to the Tropics of the Spiraea Aphid, Aphis spiraecola Patch ${ }^{1}$
}

\author{
George N. Wolcott ${ }^{2}$
}

\section{INTRODUCTION}

The first recorded occurrence of the spiraea aphid, Aphis spiraecola Patch, was on bridalwreath, Spiraea prunifolia, on the campus of the Agricultural College at Fort Collins, Colo., in 1907, by C. P. Gillette (6). ${ }^{3}$ It was not noted subsequently at this locality by him, however, but on a collecting trip in June 1910, he found it at Washington, D. C., at three localities in both New York and Massachusetts, and at two localities in Michigan. Noting its close similarity to $A$. pomi DeGeer, he tentatively identified it as $A$. spiracella Schoutenden. From material collected at Orono, Maine, Edith M. Patch described it as A. spiraecola (9).

At that time, and for $10^{\circ}$ years more, it attracted no attention, being of very minor importance economically, and not being noted as attacking any other than species of Spiraea. Dozens of ornamental and horticultural varieties of this species are grown in the northern United States, besides two wild, endemic species: Meadowsweet or pride of the meadow, and hardhack or steeplebush, which presumably were the original hosts. These have an extensive distribution in burned-over or deforested areas of minor agricultural value, mingled with poplar, huckleberry, and moss, or on stream or lake margins, or along roadsides. On both its wild and cultivated hosts, this aphid-rarely so abundant as to be actually injurious to its host and definitely causing no apparent stunting even on watershoots, nor curling of the leaves at any time-may be considered as extremely well adjusted to its specific ecological niche, which presumably it had unobtrusively occupied for a long time before being observed by an entomologist.

Hatching of the black, overwintering eggs of $A$. spiraecola Patch in the spring in northern New York (region around and to the north of Barneveld, Oneida County) coincides with the opening of the buds of bridalwreath. Many stems of flower clusters may be found heavily infested before the flowers begin to open, with development of the aphids so rapid that a second generation may begin to appear within a week after the hatching of the eggs. Maggots of Syrphid flies may attain full size on such colonies

1 From a paper presented at the sixty-fifth annual meeting of the Entomological Society of America at Los Angeles, Calif., December 1953.

2 Entomologist and Head of Department, Agricultural Experiment Station, University of Puerto Rico, Río Piedras, P. R.

3 Numbers in parentheses refer to Literature Cited, pp. 39-40. 
without appreciably reducing the crowding of the aphids. When the flowers begin to open, however, lignification of their stems is so rapid that they quickly cease to remain attractive to the aphids, and all subsequent mass infestations are on watershoots.

The large black ants, presumably the same Formica fusca var. subsericea Say (tentatively identified by M. R. Smith, Entomology Research Branch, ARS, USDA, assigned to the U. S. National Museum) that are invariably to be found on peony buds, attracted by their dark, gummy exudations, may appear on bushes of bridalwreath as attendants on the aphids. Usually only a single ant will be noted on an infested watershoot, but rarely several may be present at one time on exceptionally large colonies. By the time of the first frosts of October, increasing lignification of the watershoots has largely dispersed such colonies into a few black-winged adults surrounded by six to nine bright-green nymphs on the underside of leaves.

During the next few weeks, with ever lower autumnal temperatures, the increase in numbers of both adults and nymphs almost covers the underside of such leaves, which are turning yellow, orange, or purple above, but from below appear bright green from the aphids resting and feeding on them. By the end of October many nymphs are moving downward onto the main branches, and shining oval green eggs, subsequently turning black, will be noted crowded into every crevice beneath loose bark or at the axils of the twigs. Despite this deflection, the colonies on the leaves appear to be as large as previously, but this is presumably due to an increase in size of the individual nymphs. Both adults and nymphs persist on the leaves, even after killing frost in early November, especially on the more hardy, cultivated species. of Spiraea of which the leaves are still green.

\section{DISPERSION OF THE APHID}

The change in status from an obscure inhabitant of a wild host to a major insect pest of an economic crop is possibly best authenticated in the case of the Colorado potato beetle as being due to the constantly expanding area over which potatoes were grown. For many other insect pests, the extension of their range, and the intensity of their damage results from accidental introduction by man from areas in which they are but minor pests. But in all of these cases climatic conditions were similar, and the new economic hosts attacked, if not identical, were at least botanically closely related. By contrast, the spiraea aphid seems unique, for its dispersion to the semitropics, and shortly thereafter to the Tropies, almost necessarily resulted in a complete change in hosts. To be sure, many of the hosts reported as attacked, possibly only experimentally so far as the aphids were concerned, belong to the Rosaceae, but the most important 
are widely different botanically. One can but speculate as to what factor caused such a broadening change in the aphid's character without loss of its ability to survive on the comparatively rare spiraea plants in the subtropical regions to which it had spread. Such a loss in specificity, for which there is no apparent reason, was indeed a necessity if it were to spread and survive outside of its limited original environment.

Citrus growers in the southwestern part of the Orange Belt of Florida, in April 1924, noticed a very marked curling and rosetting of the new flushes of growth on their trees, and by June of the same year this same affliction had assumed the proportions of serious injury all over the State (11). No aphid other than A. spiraecola produces such very marked and very obvious distortion of citrus leaves, and this in equally marked contrast to the absence of such effect on its original host.

Such conspicuous injury could not long escape observation by entomologists wherever it might occur, and specimens were collected by $\mathrm{H}$. $\mathrm{K}$. Plank on citrus at Central Jaronu, Cuba, June 15, 1926, which were identified by P. W. Mason as A. spiraecota. This record was sent to J. A. Hyslop, at that time in charge of the Insect Pest Survey of the Bureau of Entomology, USDA, by D. L. Van Dine, Director of the Cuba Sugar Club.

\section{OCCURRENCE IN PUERTO RICO}

Actually, this record is antedated by that given by S. C. Bruner (4) who wrote: "Fué una sorpresa cuando, un poco más tarde, (Julio 1, 1924) encontramos algunas ramas de naranjos atacadas por esta nueva plaga en Santiago de las Vegas." Somewhat later he found it in the Provinces of Pinar del Río, Habana, Santa Clara, and Camagüey, which would make its appearance in Cuba almost coincident with that in Florida. Such a record is by no means surprising, for Cuba is not far from Florida. But on October 23, 1926, S. D. Whitlock "intercepted" this aphid on grapefruit foliage at Mayagüez, P. R. (12). This is really a noteworthy jump, for Puerto Rico is far from any continental area, and indeed is little closer to Florida than it is to New York.

We do not know how A. spiraecola reached Cuba and Puerto Rico so soon after it had become widespread and well established in Florida, for its importation in nursery stock seems unlikely. J. R. Watson, Entomologist of the Florida Agricultural Experiment Station, is emphatic in stating that in Florida it is "spread by flight, not by autos, trains or nursery stock." The most recent hurricane that hit Puerto Rico, San Felipe, was in 1928, or 2 years after the aphid had been observed there. Thus this particular hurricane can hardly be implicated. But hurricanes threatening Puerto Rico, often passing within a few miles of the Island, occur practically every year during the hurricane season, their usual direction 
being north-northwest, northwest or west-northwest. Thus it is not these disturbances themselves, but the backwash of hurricane winds, traveling in the opposite direction, that could possibly carry Continental insect pests such as winged aphids such a long distance.

Judging by our observations in Puerto Rico, however, A. spiraecola does not confine its attack to imported nursery stock, if that is thought to be the original source of infestation. Old and well-established grapefruit groves rarely show signs of its presence. The conspicuous rosetted watershoots most often occur on roadside volunteer seedlings of sweet or sour orange. In part, this may be because nobody in Puerto Rico for many years has been setting out commercial groves, but heavy infestations were noted in January 1952, in the one new experimental orange grove at the Lajas Substation. Indeed, as citrus-growing is no longer an important industry in Puerto Rico, the appearance of one more comparatively minor pest of citrus in 1926 was a matter of little importance, then or subsequently, if this were the only host attacked in the Tropies.

The "bunchy-top" disease of papaya, becoming increasingly abundant and serious in preventing the commercial expansion of papaya growing in Puerto Rico, was of especial interest to José Adsuar as he was beginning to specialize in virus diseases. After he, with the cooperation of Francisco Seín, Jr., in separating out only the males of Empoasca papayae Oman (10), had proved that these leafhoppers were the only vectors of this disease, he discovered a new disease of papaya on the South Coast of Puerto Rico at Ponce and Guánica. This new mosaic was invariably associated with infestations of the spiraea aphid of which collections identified by P. W. Mason were made from seven different papaya groves in March 1945, and were repeatedly observed in subsequent years.

This was not only a new disease but also a new host for A. spiraecola. Laboratory tests showed the spiraea aphid to be the vector (1) and in the field these aphids were found so omnipresent that prevention of infection in new papaya groves proved impossible. Personal inspection by Luis F. Martorell and José Adsuar (7) located both aphid and disease in Cuba and Florida in similar limited areas; the aphid only in Jamaica and St. Thomas; and neither aphid nor disease on papaya in Hispaniola. Eradication of all mosaic plants would appear to be the only practical method of preventing the further extension of this serious disease from the limited areas where it is now known to exist, and as this is nowhere being done, the future outlook for papaya production is not bright.

The mosaic disease of papaya is not the only disease of which the spiraea aphid may be the vector. "A preliminary study of aphid vectors of the mild tristeza virus in Florida shows that two kinds of aphids may transmit the virus, Aphis spiraecola Patch and gossypii Glov. The low percentages of 
successful experimental transmissions indicate that they are less efficient vectors than citricidus (Kirk.), the vector of the tristeza virus studied in Brazil" (8).

In recent years the outbreaks of the green peach aphid, Myzus persicae Sulzer, on tobacco in the States, and subsequently in Cuba, the Dominican Republic (3), and Puerto Rico (14), seemed so inexplicable in the Tropics as to justify a search for alternate hosts during the summer period when tobacco is not being grown. So far as known no peach trees still exist in Puerto Rico, but the endemic Prunus occidentalis Sw. occurs in the mountainous heights of the western end of the Island. Locally called "almendrón" (not to be confused with "almendro" or tropical almond, Terminalia catappa L.), this tree is of more especial value because its wood has proved to be notably resistant to the attack of the West Indian dry-wood termite, Cryptotermes brevis Walker, (13) and its planting is being pushed by the local Forest Service to a rather limited extent.

If the implication of the name: "green peach aphid" meant anything for this new pest of tobacco, certainly trees of almendrón should be examined for aphid infestation. In an abandoned nursery of these trees in the Doña Juana Forest of the Toro Negro Unit, a few adults and numerous nymphs of Myzus persicae were repeatedly collected in the winter and spring of 1953, but Louise M. Russell noted that fully 85 percent of the specimens were of $A$. spiraecola. All the colonies were small, and the crumpling and distortion of the leaves so characteristic of infestations on citrus were barely perceptible on the tender terminal leaves of $P$. occidentalis, and had been completely outgrown or had disappeared on the older leaves.

A. spiraecola, as identified by Russell, was found on the endemic tree locally called "corcho prieto", Torrubia fragrans (Dunn-Cours) Standley, of the family Nictiginaceae, there being heavy infestations on the underside of leaves of tender watershoots between Cayey and Aibonito in January 1953. If this was a tentative infestation, one could hardly thus consider an enormous mass infestation of the tender leaves of "jobo" or hog plum, Spondias mombin L., of the family Anacardiaceae, brought from Vega Alta by A. F. Ross in March 1953 (fig. 1). Even more extensive was that on cultivated coriander, Coriandrum sativum L., of the family Amiaceae, brought from the Isabela Seed Farm by Arturo Riollano. Julio Bird found a heavy infestation on salvia, Pluchea purpurascens (Sw.) DC, at Aibonito. In the greenhouse at Río Piedras, José Adsuar found the pods, and to a lesser extent the leaves, of an introduced ornamental, Calliandra inaequalitera, heavily infested. Possibly these are only tentative and experimental infestations, comparable to those identified by P. W. Mason on the giant milkweed, Calotropis procera (Ait.) R. Br., and on cultivated carrot, Daucus carota L., collected in Cuba by Julián Acuña y Gale, as recorded by Bruner 


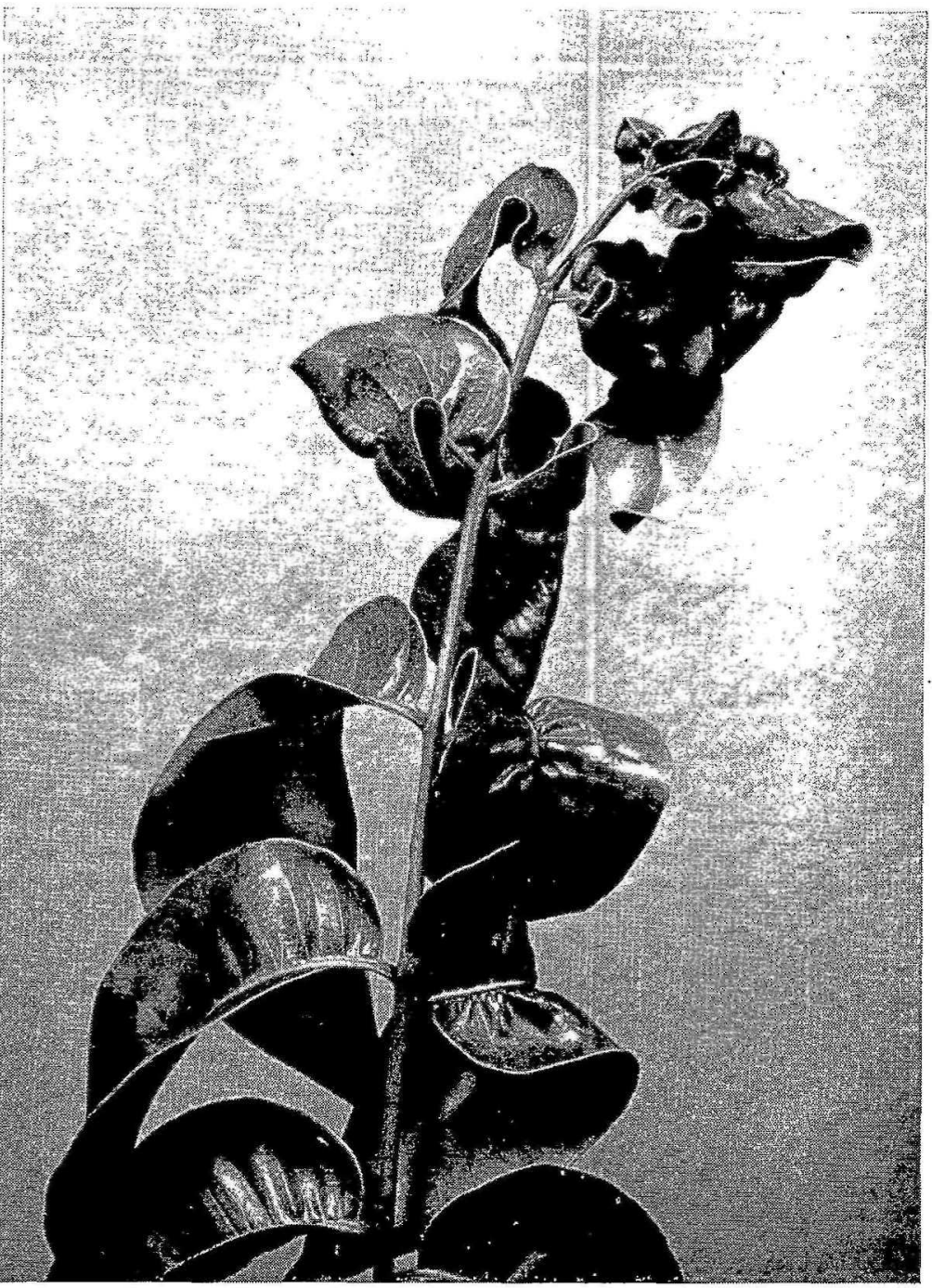

FIG. 1.-Rosetting of terminal leaflets of "jobo", Spondias mombin L., caused by Aphis spiraecola Patch. (Original, photo by Roldán).

Scaramuzza and Otero (5), and the rather extensive list given by Watson for Florida, or the even longer list compiled by Kelvin Dorward, in charge of the Insect Detection and Reporting Section of the Plant Pest Control Branch, USDA. But they unquestionably indicate an aphid no longer confined to a single host. The spiraea aphid appears ready and able to try almost anything, with ominous possibilities of becoming an even more 
serious pest of economic plants that happen to meet its increasingly elastic requirements.

\section{FURTHER DISPERSION}

The dispersion of $A$. spiraecola to the semitropics of Florida, and on to the Greater Antilles, was paralleled at a somewhat later date by occurrence on the Pacific Coast. E. O. Essig writes me that the first record is of collection by himself on the University of California campus at Berkeley, August 27, 1931, on Erica. A few days later P. S. Bartholomew found it on $\mathrm{Co}_{0-}$ toneaster at Stanford University, and in March of the following spring at the same locality on Spiraea. According to Essig, numerous collections on a variety of hosts have been made subsequently by various collectors in northern California, but dispersion northward has been slow, the first record for the State of Washington being on August 14, 1949, on Soruba at Seattle, and for Oregon: June 1, 1950, by L. G. Genther at Medford on Laurestinus. A. spiraecola was found by A. E. Michelbacher on loquat at Riverside, Calif., on April 8, 1936, and subsequently on orange at the same locality, but its abundance on citrus in California never assumed the epidemic proportions that it had in Florida.

Dispersion to the continental Tropies from its original range was much more rapid than to the western United States. Specimens collected in * Honduras (2) by R. L. Westmoreland on citrus and sent to M. M. Yothers, ${ }^{4}$ and specifically identified in the U. S. National Museum, definitely fix the date for Central America as 1928. An old Florida citrus grower in Honduras claimed that the aphid had been there for at least 10 years, but lacking the evidence of actual specimens, one may doubt such early occurrence, for Toxoptera aurantii causes a similar but not such severe curling of the leaves, which in retrospect might be remembered as the tight rosetting resulting from infestation by $A$. spiraecola. In March 1933, G. H. Ballou submitted specimens to the U. S. National Museum collected on citrus in Costa Rica, presumably indicating wide dispersion in Central America, but unrecorded elsewhere there, and possibly in northern South America also unrecorded because of lack of entomologists to make collections.

To date, A. spiraecola is not known to occur south of St. Thomas, U. S. Virgin Islands, in the Lesser Antilles. In Barbados, Trinidad, and British Guiana, personal inspection by Luis F. Martorell of papayas, in the spring of 1953 , failed to indicate the presence of the aphid there at that time. One can but speculate whether the impetus of dispersion has passed, and that the spiraea aphid will not invade South America. Possibly all the

1 Now retired, but then in the Division of Fruit Insect Investigations, Bureau of Entomology and Plant Quarantine; now Section of Fruit Insect Investigations, Entomology Research Branch, ARS, USDA. 
recent records of new host plants may be merely a temporary interest by plant pathologists and entomologists in Puerto Rico in making collections of aphids as possible vectors of plant diseases. But considering its past, one may rather expect a continuing extension of dispersion of $A$. spiraecola Pateh over an increasingly large number of hosts plants in the Tropics.

\section{SUMMARY}

The spiraea aphid, Aphis spiraecola Patch, which previous to 1924 was known only on species of Spiraea in the northern United States, in that year appeared in mass infestations on citrus trees in Florida and Cuba, causing enormous damage by distorting and resetting the young growth. By 1926 it had spread to Puerto Rico, attacking not only various endemic trees and plants, but being implicated in the transmission of a new virus disease of papaya. By 1928, it was reported on citrus from Honduras in Central America, and it has since dispersed to Costa Rica, and on a great variety of hosts to California, Oregon, and Washington on the Pacific Coast.

\section{RESUMEN}

El áfido spirea, Aphis spiraecola Patch, el cual antes del 1924 sólo se conocía que atacaba especies de Spiraea en la parte nortè de Estados Unidos, apareció ese mismo año en grandes infestaciones atacando y causando enormes daños a las cítricas de Florida. El daño que ocasiona este insecto se circunscribe a torcer y dar forma de roseta a las hojas afectadas.

En el año 1926, este insecto se extendió hasta Cuba y Puerto Rico donde ha venido atacando no sólo vạios de los árboles y plantas endémicas, si que también se le ha implicado en la trasmisión de una nueva enfermedad virosa de la papaya.

En el 1928, se informó su presencia en las cítricas de Honduras, América Central y desde entonces se ha extendido hasta Costa Rica, California, Oregon y Washington en la costa del Pacífico, donde ataca una gran variedad de árboles y plantas.

\section{LITERATURE CITED}

1. Adsuar, José, The transmission of papaya Mosaic by the green eitrus aphid, Aphis spiraecola Patch, Technical Paper No. 2, Agr. Expt. Station, Río Piedras, P. R. 1946.

2. Anon., Fla. Ent. 11 (4) 53, 1928. (Editorial).

3. Beinhart, E. C., Green peach aphid on tobacco in the Dominican Republic, Sci. 116 713-14, Dec. 26, 1932.

4. Bruner, S. C., Una nueva plaga importante del naranjo en Cuba, Revista de Agricultura, Comercio y Trabajo, año VIII: 173-74, fig. 2, Jan. 12, 1926.

5. Bruner, S. C., Scaramuzza, L. C. y Otero, A. R., Catálogo de los insectos que 
atacan a las plantas económicas de Cuba Boletín No. 63, pp 246, illus., Estación Experimental Agronómica, Santiago de las Vegas, Cuba, Septiembre 1945.

6. Gillette, C. P., Plant louse notes, family Aphididae, J. Ec. Ent. 3 (5) 404, 1910.

7. Martorell, Luis F., and Adsuar, José, Insects associated with papaya virus diseases in the Antilles and Florida, J. Ec. Ent. 45 (6) 861-69, 1952.

8. Norman, Paul A. and Grant, Theodore J., Preliminary studies of aphid transmission of Tristeza virus in Florida, State Hortincultural Society, 66 89-92, ref. 10., Daytona Beach, Nov. 3-5, 1953.

9. Patch, Edith M., Maine aphids of the rose family, Maine Agr. Expt. Station Bull. 233, 370, 1914.

10. Sein, Francisco, and Adsuar, José, Transmission of the bunchy-top disease of papaya (Carica papaya L.) by the leafhopper Empoasca papayae Oman, Sci. 106 (2745) 130, Aug. 8, 1947.

11. Watson, J. R., and Beyer, A. H., Controlling the citrus aphis, Fla. Agr. Expt. Station Bull. 174, 1925.

12. Wolcott, G. N., The insects of Puerto Rico, J. Agr. Univ. P. R. 32 (1) 151, 1948. 13. - An index of the termite resistance of woods, Río Piedras Agr. Expt. Sta. Bull. 85, 1950.

14. —, Migrating aphids, Sci. 116 (3002) 43-4, July 11, 1952. 